\title{
Conceiving the Pre-Modern Black-Arab Hero: On the Gendered Production of Racial Difference in Sïrat al-amìrah dhāt al-himmah
}

\author{
Rachel Schine \\ University of Chicago \\ rachelschine@uchicago.edu
}

\begin{abstract}
'Abd al-Wahhāb's character in Sìrat al-amìrah dhät al-himmah is but one example of a black hero who figures prominently in a sirah shabiyyah, or popular heroic cycle, the earliest references to which appear in the twelfth century and several of which remain in circulation today. Like several of his counterparts, not only is he black, but he is also alone among his relatives in being so. The explanation supplied in the text of his mother Fāțimah's eponymous sīrah for his "spontaneous" phenotypic deviation makes use of rhetoric also found in various antecedent and near-contemporary belles-lettres sources. Placing 'Abd al-Wahhāb's case within the context of this literary network illuminates a series of questions concerning the semiotics of race in pre-twelfth-century Arabo-Muslim literature, racially inflected anxieties about control of feminine sexuality, and pre-genetic syntheses of racial and reproductive "sciences." This paper concludes that 'Abd al-Wahhāb's blackness is produced through a set of scientific and speculative discourses that go beyond the prominent theories of climate influences and Hamitic genealogy, and that posit instead a racial determinacy that occurs spontaneously, regardless of geography or lineage, through a variety of interventions from and against the maternal body. These include the contamination of seminal fluid, "image-imprinting," and divine fiat. The concentration of these theories within a single text makes 'Abd al-Wahhāb's conception narrative a uniquely apt ground for discussing the broader complex of issues of gender and race in pre-modern Arabic literature.
\end{abstract}

\section{Keywords}

race - sīrah - hero - black - adab - gender - sexuality - Africanicity 
The sirah shabiyyah (pl. siyar) texts make up a corpus of heroic cycles that magnify the lives of great warriors in the Arabo-Islamic tradition. Originally performed orally for a popular audience, ${ }^{1}$ they bear similarities to early Islamic "chivalric" works such as chronicles of conquests and military raids; likewise, the sirahs memorialize superhuman martial triumphs while maintaining a historicizing and often didactic tone. ${ }^{2}$ Several early sirah shacbiyyah cycles include black-Arab heroes as significant agonists, ${ }^{3}$ a number of whom are born to self-identified "white" Arab parents. Among the black heroes in the early sirahs are 'Antar (based on the pre-Islamic poet 'Antarah ibn Shaddād) and his daughter 'Unaytirah in Sirat 'Antar, chronologically the first of the sirahs; Abū Zayd al-Hilālī (né Barakāt) of Sìrat Banı̄ Hilāl; and 'Abd al-Wahhāb, son of Fāṭimah Dhāt al-Himmah in her eponymous sìrah, Sìrat al-amìrah dhāt al-himmah. These latter two heroes-Abū Zayd al-Hilālī and 'Abd al-Wahhābexhibit the phenomenon of "spontaneous" blackness. This study focuses on 'Abd al-Wahhāb's conception, birth, and subsequent paternity trial (henceforth his "conception narrative"). ${ }^{4}$

1 Though this article will focus on a textualized sirah, significant work has been done on the sirrahs' oral transmission, with particular focus on the extant Hiläliyyah tradition. See Dwight F. Reynolds, Heroic Poets, Poetic Heroes: The Ethnography of Performance in an Arabic Oral Epic Tradition (New York: Cornell University Press, 1995); Susan Slyomovics, The Merchant of Art: An Egyptian Hilali Oral Epic Poet in Performance (Berkeley: University of California Press, 1987).

2 For a comparison across these genres, see H. T. Norris. "The Futūḥ al-Bahnasā: And its Relation to pseudo-'Maġāzì' and 'Futūḥ' literature, Arabic 'Siyar,' and Western Chanson de Geste in the Middle Ages," Quaderni Di Studi Arabi 4 (1986). On the historicity of the sirahs, see T. Herzog, “'What they Saw with their Own Eyes ...': Fictionalization and 'Narrativization' of History in Arab Popular Epics and Learned Historiography," in Fictionalizing the Past: Historical Characters in Arabic Popular Epic, ed. Sabine Dorpmueller (Leuven: Peeters Publishers and Department of Oriental Studies, 2012); Peter Heath, "Other sīras and Popular Narratives," in Cambridge History of Arabic Literature: Arabic Literature in the Post-Classical Period, vol. 6, ed. Roger Allen and D. S. Richards (New York: Cambridge University Press, 2006); M. Canard, "Dhü'l-Himma," in Encyclopaedia of Islam, ed. P. Bearman et al. (Leiden: Brill, 2016).

3 I reference Madeyska's category of early sirahs (those composed prior to the twelfth century). See Danuta Madeyska, "The Language and Structure of the 'Sīra," Quaderni Di Studi Arabi 9 (1991). On the dating of Sirat dhät al-himmah, see Remke Kruk, Warrior Women of Islam: Female Empowerment in Arabic Popular Literature (London: I. B. Tauris, 2014), 39.

4 The text of Sirrat dhät al-himmah that has been used throughout is the 1909 Cairo edition: 'Alī b. Mūsā al-Maqānibī b. Bakr al-Māzinī and Șālih al-Jacfarī, Sìrat al-amīrah dhāt al-himmah, vol. 1 (Cairo: Maktabat al-Mațbáah al-Husayniyyah, 1909). This edition has been used both as a function of its being one of the earlier, most readily accessible print editions of the sirrah, 
According to the sirah, after being forcibly wed to her cousin al-Hārith, the heroic, chaste military general (amīrah) Fātimah Dhāt al-Himmah, who had risen in the ranks after coming of age and studying martial arts while in the captivity of another tribe, is drugged and the marriage is consummated by rape. ${ }^{5}$ She then bears a black son, her first and only child, 'Abd al-Wahhāb. His blackness is met with horror and confusion by all, compelling Fāțimah to hide the child away until it is no longer possible to do so, at which point both 'Abd al-Wahhāb's legal proceedings and heroic legacy begin simultaneously to unfold. Ultimately, it is found that 'Abd al-Wahhāb's coloration is the result of al-Hārith having copulated with Fāṭimah during her menses: the "black" color of her menstrual discharge mixed with the embryogenic nutfah (sperm-drop), dyeing it. ${ }^{6}$ Within the narrative, this ruling is delivered by none other than the sixth Shīīi imam, Jaćar al-Ṣādiq.7

and in order to accord with the findings of other scholars such as Canard and Kruk, who have worked with this edition of the sirah specifically.

5 The language of rape and sexual violence is fraught with respect to pre-modern sources. Most recently, Hina Azam has treated the issue of "translating" sexual violation across language, space, and time in her book Sexual Violation in Islamic Law: Substance, Evidence, and Procedure. Azam rightly states that due to the incommensurability between modern presumptions of female volition and autonomy and pre-modern conceptions of women as property, we must "seek out disparate discursive and legal categories" for classifying sexual violation in late Antique and medieval texts. With this in mind, I have elected to refer to Fāṭimah's sexual encounter with al-Ḥārith as rape for two reasons. First, Fāțimah was wed unwillingly, a contract that is contestable according to multiple Islamic legal paradigms. Second, within a modern reading practice, I affirm that not calling Fāțimah's sexual violation a rape is to perpetuate the very rhetoric that has historically precluded the recognition of women as agentive, autonomous, and deserving of having their experiences of physical and psychological violation acknowledged. See Hina Azam, Sexual Violation in Islamic Law: Substance, Evidence, and Procedure (New York: Cambridge University Press, 2015), 17.

6 A comparable case occurs in Sïrat 'Antar, wherein 'Antar is pitted against an Indian child, the son of King 'Abd Hayyāf, who was born black due to his mother having been raped while menstruating, although the child is cast as an anti-hero. See Malcolm Lyons, The Arabian Oral Epic: Heroic and Oral Storytelling, vol. 3 (New York: Cambridge University Press, 1995), 60.

7 The text of Sirrat dhät al-himmah is, to say the least, palimpsestic, and its composition, as well as its narrative, are diachronic and difficult to place. As will be seen, in its early twentiethcentury Cairo edition, the sirah incorporates a number of ostensibly shīì-leaning pietistic themes and references, and indeed many of the heroic features in the sirah are shared by figures such as Husayn b. 'Alī in Shī'ì martyrdom narratives, or maqātil, which developed into an independent genre around the tenth century. A fruitful comparison could, in the future, be made between these two literatures. See Sebastian Günther, "'Maqâtil' Literature in Medieval Islam," Journal of Arabic Literature 25 (1994), 209-210; Khalid Sindawi, "The Image of Husayn ibn 'Alī in 'Maqātil' Literature," Quaderni di Studi Arabi 20/21 (2002-2003). 
Non-hereditary black births like that of 'Abd al-Wahhāb are attested not only in these sirahs but also in a variety of earlier belletristic (adab) sources spanning jurisprudential, medical-scientific, and exegetical genres. Within the broader ambit of "world literature," 'Abd al-Wahhāb's blackness may seem a mere exponent of the heroic literary genre; every hero from Achilles to Wonder Woman is beset by a handicap that must be overcome in the course of his or her superhuman feats. However, I argue that the medical aberration that constructs 'Abd al-Wahhāb's blackness transcends genre and folkloric typologies. Instead, it indicates the development of a multifarious set of racialist theories - that is, theories that seek to itemize and hierarchize types of racial diversity-in Arabic scholarship and literature of the early medieval period that had evolved in addition to the prevalent climatological explanation of race, which adduced humoristic factors such as heat and wetness in a given location as giving rise to racial differentiation (sub-Saharan Africa, being hot and dry, blackens its inhabitants and curls their hair). ${ }^{8}$ These theories also diverge in their epistemic preoccupations from occult explanations for racial differentiation found in popular prophetology, which in the Islamic tradition typically traces the etiology of race to a curse on Noah's son, Ham. ${ }^{9}$ These scientific and speculative formulations filtered into popular literature and, transitively, into popular discourse, becoming widespread and well entrenched by the mideleventh century across a vast geography - the belletrists cited in this paper span al-Andalūs to Baghdad—at least half a century before the earliest sirrahs come into evidence. ${ }^{10}$

8 I shall use the term "racialism" throughout to signify the theoretically supported assumption of a hierarchic system of races, predicated mostly on ethno- or cultural-centrism rather than on its negative counterpart, xenophobia (with this being a defining quality of racism). I have selected this term also out of a desire to differentiate modern racist sciences, which actively sought to dehumanize "lower races," from pre-modern racialist sciences, which typically averred the "common descent of all human beings" from Adam, but nonetheless maintained their hierarchic ordering. See Robert Bartlett, "Medieval and Modern Concepts of Race and Ethnicity," Journal of Medieval and Early Modern Studies 31 (2001), 44; Geraldine Heng, "The Invention of Race in the European Middle Ages I: Race Studies, Modernity, and the Middle Ages," Literature Compass 8/5 (2011). On climatological race theory in the pre-modern Middle East, see Bernard Lewis, Race and Slavery in the Middle East: An Historical Inquiry (New York: Oxford University Press, 1990).

9 On the centrality of the Hamitic legend to the portrayal of Africans and blacks in Arabic literature, see Xavier Luffin, Les fils d'Antara: representations des Africains dans la fiction arabe contemporaine (1914-2011) (Brussels: Éditions Safran, 2012), 10-12. (See also notes 27-32.)

10 Kruk, 3 . 
As such, I argue, 'Abd al-Wahhāb's character cannot be read as a straightforward avatar of 'Antar, a hereditarily black sirah protagonist with pre-Islamic roots. ${ }^{11}$ Nor does 'Abd al-Wahhāb's blackness act as an ambivalent placeholder for any number of social handicaps in the heroic literary stockpile. ${ }^{12}$ Rather, having come into existence through an obscure process that is puzzled out before the readers' eyes, 'Abd al-Wahhāb's initial moment of "construction" as a character, namely his conception, is particularly useful for parsing perceptions of how race- or more specifically, blackness—is physiologically and societally situated in pre-modern Arabic literature.

With respect to studies of race in the pre-modern era, Geraldine Heng offers a critique that such research has focused overmuch on representing race as a set of "biological or somatic features [...] selectively moralized" to effect social control, rather than envisioning race as itself a "structural relationship for the articulation and management of human differences."13 In view of this critique, this article presents two correctives for reading race in pre-modern Arabic texts. First, it analyzes a kinetic moment of racing, wherein 'Abd alWahhāb's blackness is being created and actively incorporated into the power structures of the text. Second, this study aims to widen the scope of our understanding of the biological features and processes that were of utility to medieval Arab thinkers and popular narrators alike with respect to constructing race, thus displacing the scientific aspect of racial thought from its perceived high cultural purview. Indeed, even if we are to accept Malcolm Lyon's hypothesis that some large portion of audiences for the sirahs must have been black in order to propel characters such as 'Abd al-Wahhāb to eminence, we must

11 This claim has been suggested in various places-Malcolm Lyons attributes it to the entrenched archetype of the strong black warrior, which 'Antar first embodies. Accordingly, the "genetic accident" common to Abū Zayd al-Hilālī and 'Abd al-Wahhāb forces the issue of their "passing" as slave soldiers. Peter Heath notes that the nineteenth-century Orientalist Joseph Von Hammer-Purgstall, for his part, regarded 'Antar himself as the sycophantic fabrication of the litterateur 'Așma'ì (d. circa 828) — the text's alleged authorbecause he wished to ingratiate himself with the half-black caliph Ma'mūn (d. 833). See M. C. Lyons, The Man of Wiles in Popular Arabic Literature: A Study of a Medieval Arab Hero (Edinburgh: Edinburgh University Press, 2012), 216; Peter Heath, The Thirsty Sword: Sïrat Antar and the Arabic Popular Epic (Salt Lake City: University of Utah Press, 1996), 6.

12 Cf. Bridget Connelly, Arab Folk Epic and Identity (Berkeley: University of California Press, 1986), 149-154.

13 Heng, "The Invention of Race," 262. 
also acknowledge that the ways in which black heroes are introduced into the sirahs are not accidental; their existence is strategically conjured and justified. ${ }^{14}$

The racialist theories applied to 'Abd al-Wahhāb's condition in the text of Sirat dhät al-himmah fit within a broader, comprehensive hermeneutic for evaluating racial difference. Two main assumptions underpin this hermeneutic: first, that whiteness (inasmuch as the Arabs regarded themselves as white) is unadulterated and ideal, whereas blackness is a product of miscegenation, contamination, or acclimatization; and second, that female sexuality forms the domain in which these racially determining events occur. This article therefore analyzes this confluence of racially determining elements in 'Abd al-Wahhāb's narrative, and ultimately asserts that the racialist theories applied in affirming 'Abd al-Wahhāb's legitimacy all express a common anxiety less about the black body proper than about the female body as a locus in which blackness can be-often against one's will-implanted and incubated. Although these methods of implantation are all scientifically rationalized, they bolster an irrational premise - namely, the possibility of offspring that is neither illegitimate nor, ostensibly, hereditarily related to his parents; one precarious body produces another.

'Abd al-Wahhāb's conception narrative may thus be seen as an allegory of what sociologist Orlando Patterson has termed "natal alienation," by means of which an individual born into slavery is dissociated from all "rights' and claims of birth" and outcast from legitimate social and political arrangements. ${ }^{15}$ Whereas 'Abd al-Wahhāb is not born into slavery, but rather into blackness (although the two are frequently conflated by his peers), his version of natal alienation leaves him dispossessed of a different kind of social legitimacy and birthright: a normative and readily intelligible lineage. ${ }^{16}$ The dislocation of 'Abd al-Wahhāb's race from its "rightful" heritage is brought into effect by a literal bodily intervention from his mother, whose body and its uniquely female vulnerabilities constitute the domain in which racial expression is manifested and manipulated.

The explicit connection forged between the black body of 'Abd al-Wahhāb and that of his mother is supported not only by the association drawn between Fāțimah's menstruation and 'Abd al-Wahhāb's coloration, but also by biological

\footnotetext{
14 Lyons, Arabian Epic, vol. 1, 24.

15 Orlando Patterson, Slavery and Social Death: A Comparative Study (Cambridge, MA: Harvard University Press, 1982), 5 .

16 On uses of the term 'abd and the conflation of slave status and blackness in the sirahs, see Lyons, Arabian Epic, vol. 1, 25.
} 
discourses concerning mother-child bonds and by moralizing discourses that marshal a woman's bodily functions to circumscribe male behavior. ${ }^{17}$ Nonetheless, these interrelated forms of alterity - femaleness and blacknesshave seldom been brought together in a single study of pre-modern Arabic sources. And yet, the imbrication of race and gender is a societal inevitability. This phenomenon is described by Heng as an inbuilt capacity of "racial logic," whereby race "stalk[s] and merge[s] with other hierarchical systems—such as class, gender, or sexuality."18 This study sketches the terms in which a discussion of these commingling aspects of identity may take place: What is the relationship of blackness to gender in the sirah? What does it mean that this relationship is drawn through a scientific aberration rather than an organic arrangement? What types of affinity are being permitted and denied, and to what end?

In the course of analyzing the text of the sirah itself, I incorporate various companion sources from the Prophet Muhammad's sayings (hadith), the works of Jacfar al-Ṣādiq (d. 765) (both those that are traditionally considered to be authentic and those that are questionably attributed), Jewish scripture and lore (isrǟiliyyāt) as featured in the works of Ibn Hazm (d. 1064), stories of the prophets (qișaș al-anbìy $\bar{a}$ ), and medical theories used by Abū 'Uthmān 'Amr ibn Bakr al-Jāhiz (d. 868) and others. I have chosen these sources for their geographic and temporal distribution, and because of the popularity that their authors achieved in their own lifetimes, leading their intellectual enterprises to be widely promulgated and emulated. From these works, three predominating theories explaining non-hereditary black birth may be deduced: imageimprinting, chemical contamination of the nutfah (sperm-drop), ${ }^{19}$ and divine providence. The Classical theory of atavism (a notion developed by Aristotle explaining the sudden re-expression of long-dormant ancestral traits) appears as well. ${ }^{20}$ Each of these etiological theories is tested in the sirah, and so these sources will be used to frame corresponding movements within the sirah itself.

17 These discursive patterns inhere in the common practice of binding male sexual and behavioral norms to female biological processes such as menstruation or pregnancy. On this, see Y. Linant de Bellefonds, “Idda," in Encyclopaedia of Islam.

18 Heng, 262.

19 Because of the technicality of its definition and frequency of its appearance, the word nutfah will be used in the original Arabic throughout.

20 Aristotle, Aristotle on the Generation of Animals: A Philosophical Study, trans. Johannes Morsink (Lanham, MD: University Press of America, 1982), Book IV. 


\section{Dangerous Conception: Fāțimah's Impregnation and 'Abd al-Wahhāb's Birth}

The staging of Fāțimah's forced consummation prefigures the scientific scrutiny that the sirrah will later apply to 'Abd al-Wahhāb's conception. This is evident in the depiction of the drug used to entrap Fāțimah, administered by her companion Marzūq, who received it from another man named 'Uqbah,

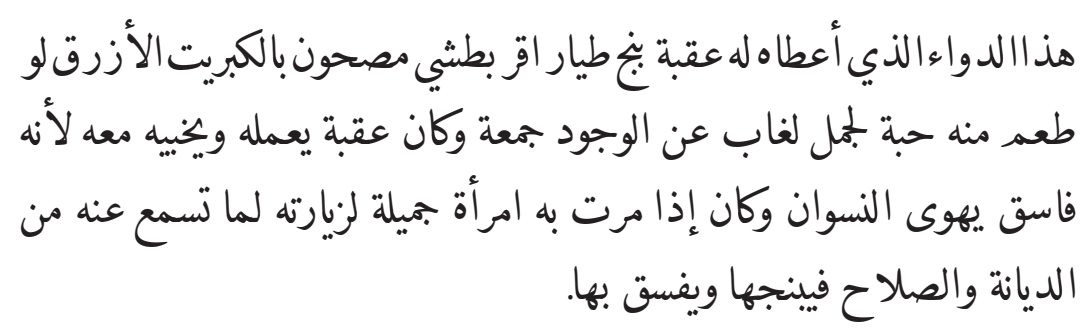

[T] his was the drug which 'Uqbah gave to him: a volatile, overpowering soporific, ground up with a blue-hued sulfur. Should a camel taste but a grain of it, it would lose consciousness through all of Friday. And so 'Uqbah would make [such a drug] and would conceal it on his person, because he was a corrupt one, impassioned by women. And when a beautiful woman happened his way for a visit, that she might hear from him talk of piety and righteousness, he then would drug her and do wrong by her. (viI: 9$)^{21}$

This vividly detailed pharmacological description is delivered in a mode of scientific and pseudo-scientific speech that will echo throughout the portions of the text in question. After Marzūq slips the drug into Fāțimah's drinking goblet, she falls as unconscious and inert "as a plank of wood." Al-Hārith then moves in to have his way with her:

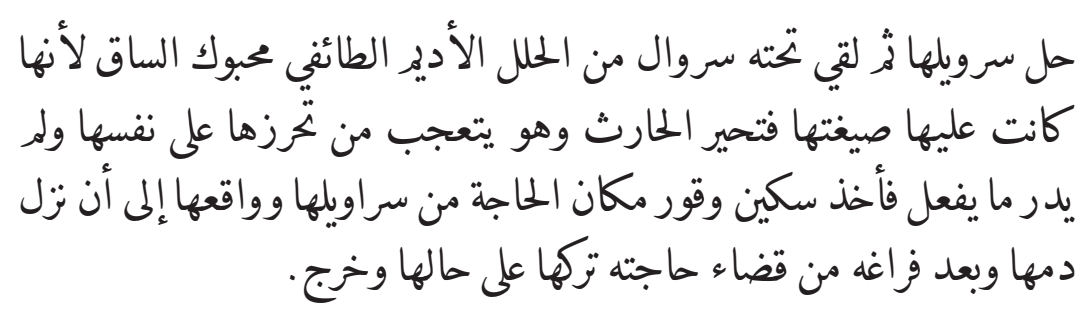

21 Section and page numbers for the sirrah translations will henceforth be produced as above (section, page number). 
$[\mathrm{H}] \mathrm{e}$ undid her trousers, then he encountered drawers beneath them of well-worked, paneled leather, with well-knit legs, for they were closefitted upon her form. Al-Ḥārith grew bewildered, and he was astonished by her safeguarding of herself, and he did not know what to do. He took a knife and gouged out a place from her trousers as needed, and he copulated with her until her blood issued out. After he had finished satisfying his need, he left her as she was and departed. (VII: 10)

The language used here adumbrates a causal relationship between the rape and Fāțimah's bloodshed. The use of the third form of $w_{-}^{-q^{-}}$, which can mean, depending on the gender of the subject and the context, either "to attack" or "to have intercourse with," here seems to carry both meanings simultaneously, particularly in light of Fāțimah's predominant identity as a warrior, which is often set over and against her femininity. We may therefore read this as a double entendre; al-Ḥārith is attacking Fāțimah by means of coition. ${ }^{22}$

The language in this instance does not explicitly indicate the fact of Fāțimah's menstruation that later surfaces, nor does it indicate that al-Ḥārith takes notice of the blood. Rather, the audience is left believing that, being as this is Fātimah's first sexual encounter, the blood is a natural result of her hymen tearing. Nonetheless, the violent language used foments discomfort for the reader. This is not a consummation, but rather a violation, and one that is ambiguous in terms of the degree of physical injury inflicted upon the victim because the source of the ensuing emission of blood is left unnamed. Al-Hârith departs, unrepentant, and is subsequently compelled to flee from a remorseful Marzūq's wrath. He does not see Fāțimah again until after 'Abd al-Wahhāb is born and his parentage is cast into doubt.

The description of 'Abd al-Wahhāb's birth bears further analysis not because of its exceptional nature, but rather because of its normalcy. It is couched in references to divine will and creative power, which serve to reinforce the notion that bearing a child, regardless of its kind, is a divinely sanctioned experience:

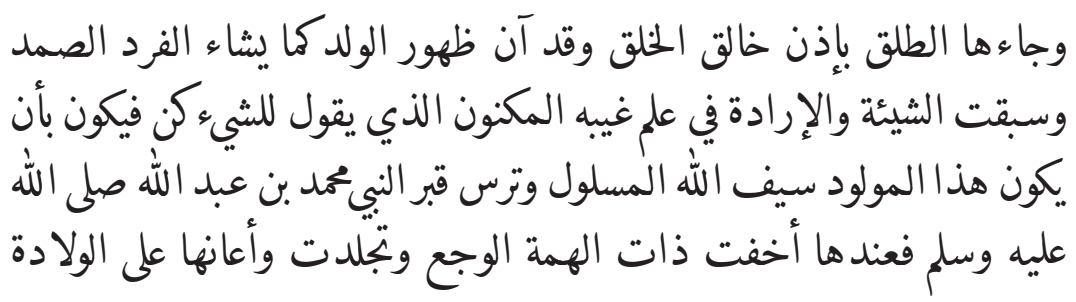

Muḥammad b. Mukarram b. Manẓūr, Lisān al-'arab (Beirut: Dār Ṣādir, 1955), 4896. 


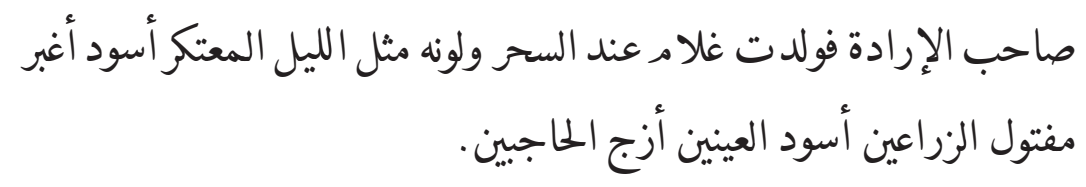

Labor came upon her, by the allowance of the Creator of Creation, and so there appeared a son, as the singular eternal one wills, and volition and will is preceded by his hidden, esoteric knowledge, with which he says "be," and so it is. Thus he did bring into being this birth of the unsheathed sword of God and shield of the grave of the Prophet Muhammad b. 'Abdullāh, peace be upon him. Though at the time the pain frightened Dhāt al-Himmah, she held fast, and the Master of Will helped her. She then gave birth to a boy at the approach of dawn, and his color was like the turbid night, black and dunn-like, taut of limbs, black of eyes, and with beautifully arched brows. (VII:11)

Particularly striking here is the use of the title "eternal one," or șamad, for God. This epithet occurs once in the Qurān, in the sūrah of "The Sincerity" (al-Ikhlās), which also features a monotheistic catechism refuting the existence of divine ancestors or descendants by affirming that God "neither begets nor is born" ( $Q$ 112:3). It is interesting that this reference should figure in a birth narrative. The allusion reminds the audience that although God has no descendants - which is to say, he does not reproduce - he nonetheless retains supreme creative power. This cleaves the process of creation from that of reproduction and obviates Fāțimah's responsibility for the nature of her child. Indeed, when her attendants beg Fātimah to confide her in them and confirm their suspicions that she has committed adultery, Fāțimah herself says simply, "seek refuge in God [...] lo this child is a craft [șinā'ah] of the most able king [al-malik al-qādir]," who alone can raise the dead among the living and draw black beings from white ones. That is, Fāțimah herself elevates the trope of woman as mere vessel into a sublime alibi for her child's condition, which is represented as a testament to God's unique ability to not only create, but to embellish and transform, reanimating inert, dead flesh and rendering black into white. This is further supported by her referring to her son not simply as a "creation," but instead uses a term that connotes a fabricated object (șina'ah) made by a master craftsman. In keeping with this division between birthing and bringing into being, the passage also features a recurrent Qur'ānic formulation for God's capacity for creation through speech. He merely says, "be," and it is (kun fayakūn). ${ }^{23}$ In this sense, 'Abd al-Wahhäb's birth is expressed as being both as common and as miraculous as any other act of creation. 
Blood - a substance that proves particularly relevant to 'Abd al-Wahhāb's etiology - is part of the natural-supernatural matrix of elements necessary for reproduction, intrinsic to humans yet used by God to wondrous and sometimes unexpected ends. Many litterateurs, including the prolific al-Jāhiz, his near-contemporary Ibn Qutaybah, and Jaffar al-Ṣādiq, developed theories pertaining to blood's reproductive functions. All share the common belief that the blood that a woman would otherwise lose through menstruation is diverted to the womb to encase and nourish the child. Other fluids, such as the male and/ or female nutfah, mingle prior to the embryonic ingress into the blood-sac of the woman's womb. Medieval Arab physicians and theologians were divided on whether this nutfah was indeed a mixture of ejaculates contributed by both male and female, or whether it was exclusively male; this debate roughly follows the divide between the Hippocratic and Aristotelian theories of reproduction that reigned throughout Antiquity. ${ }^{24}$ Whereas for Hippocrates, both male and female could produce a seminal discharge, Aristotle averred not only that women could not emit semen, but that their menstrual blood was moreover a result of the same physiological process through which males generate semen, namely drawing nourishment from one's organs to then concoct and nourish another body. Undergirding this is the notion that women's humors are less balanced, rendering them reproductively deficient and dependent. ${ }^{25}$ With respect to the Qurān, Kathryn Kueny names the Hippocratic modelwherein the fetus "comes into being" at the very time that its flesh, blood, and bone come into existence (the stage at which another "creation" is twinned with the fetal matter) - as according most closely with the scripture's sevenstage process, outlined in Sürat al-mu'minin (Q 23:12-14):26

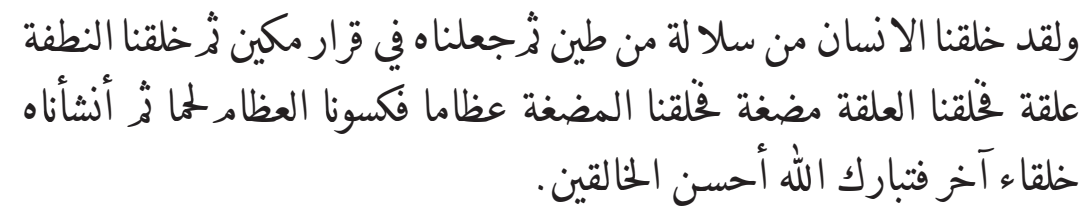

We created man of an extraction of clay, then We set him, a drop, in a receptacle secure, then We created of the drop [al-nutfah] a clot then We created of the clot a tissue then We created of the tissue bones then We

24 Etin Anwar, Gender and Self in Islam (London: Routledge, 2006), 75; Kathryn Kueny, Conceiving Identities: Maternity in Medieval Muslim Discourse and Practice (Albany: State University of New York Press, 2013), 28-31.

25 Basim Musallam, Sex and Society in Islam: Birth Control Before the Nineteenth Century (New York: Cambridge University Press, 1983), 43-44. 
garmented the bones in flesh; thereafter We produced him as another creature. So blessed be God, the fairest of creators!27

Blood first becomes reproductively relevant after the seminal entity is formed, though before the fetus itself becomes a mass of blood, flesh, and bone. Theoretically, blood should not interact with other sexual fluids until the stage at which the 'alaqah ("clot," or embryo) lodges itself in the uterus. According to most medieval Arabic medical-scientific texts, blood diverted for gestational uses is not evaluated as impure or disgusting in the way menstrual blood generally is. This is notably untrue, however, in the case of the Nusayrī Ismāîli text al-Haft al-sharîf, attributed to Ja'far al-Ṣādiq, the same Shī'ì imam who appears within the text of Sirat al-amirah dhät al-himmah. ${ }^{28}$ This text claims that God instrumentalizes the bloody environment of the womb against infidels ( $k \bar{a} f i r u \bar{n})$ by "ensouling" their bodies much earlier than their believing counterparts: 29

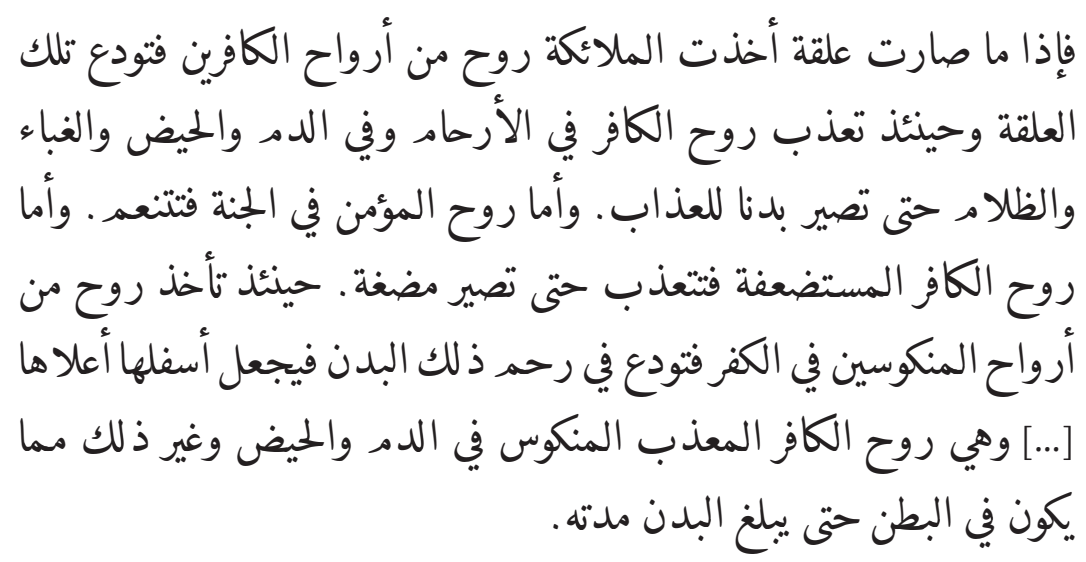

27 A. J. Arberry, The Koran Interpreted: A Translation (New York: Touchstone, 1996), 353.

28 This work is also known by the title al-Haft wa-al-azillah; see Ja'far al-Ṣādiq and Mufaḍdal b. 'Umar al-Ju'fì, al-Haft al-sharīf, ed. Mușțafā Ghālib (Beirut: Dār al-Andalūs, 1964). See also Farhad Daftary, Ismaili Literature: A Bibliography of Sources and Studies (New York: I. B. Tauris, 2004), 163; Mushegh Asatryan, "Mofazzal Al-Jo'fi," in Encyclopedia Iranica (New York: Encyclopedia Iranica Foundation, 2012), http://www.iranicaonline.org/articles/ mofazzal-al-jofi.

29 "Ensoulment," as the term suggests, represents the time at which the soul of an unborn human enters its body. There is not a consensus in early tafsir writings on when exactly this occurs, although several exegetes such as al-Ṭabarī do introduce the concept in exegeses of Q 22:5. See Abū Ja‘far Muhammad b. Jarīr b. Yazīd al-Ṭabarī, Jāmi 'al-bayān fì ta’wìl al-Qur'ān, http://altafsir.com/Tafasir.asp?tMadhNo=o\&tTafsirNo=1\&tSoraNo=22\&tAyah No $=5 \&$ tDisplay $=$ yes\& UserProfile $=0$ \&LanguageId $=1$. 
Then, when [the embryo] becomes an attached thing, the angels take a spirit from amongst the spirits of the infidels, then they put it into that attached mass and the spirit of the infidel is tortured in the [layers of the] womb, in the blood and the menstrual secretion and the darkness and the obscurity until it becomes a body, for [the purpose of] castigation. As to the spirit of the believer, it is luxuriating in the Garden. As to the enfeebled spirit of the infidel, it is tortured until it becomes a small lump of flesh. Thereupon, a spirit from among the spirits of those who have lapsed into infidelity is taken. And that body is lodged in the womb, then it is turned upside down [...] and it is the spirit of the tortured infidel, inverted in the blood and menstrual secretion and other things that are within the belly, until the body has reached its term. ${ }^{30}$

Although the author imagines the womb's menstrual blood as an ordeal for the unbeliever, he does not imply that the blood in any way taints the infidel or permeates his body. Rather, the infidel is already ipso facto tainted. And yet, Jafar al-Ṣādiq is unique in his preoccupation with menstrual blood as an affecting substance that disturbs the fetus, whereas for other scholars it was typically an unremarkable natural condition of the womb. Jafar moreover offers an instance of the blood's instrumentality; it is a means to the end of afflicting the unbeliever much in the way that it will come to cause 'Abd al-Wahhāb's problematic coloration.

The intermixing of corrupting or colorful fluids at conception is posited elsewhere as exerting a permeating effect, coloring the child. Such is the case in both Tha'labì's (d. circa 1036) and al-Kisâ̄î's (d. circa 805) recountings of the story of Noah and his sons, recorded in their respective collections of stories about the prophets, or qișaș al-anbiy $\bar{a}{ }^{3}{ }^{31}$ In each case, a different admixture of substances transforms Ham and his offspring into the first black people ever to exist. These etiologies of race, a narrative subgenre typical to anthologies of stories of the prophets, provide one of the closest points of comparison to the etiological stories of black heroes in the sirah sha'biyyah texts. ${ }^{32}$

\footnotetext{
30 al-Șādiq and al-Ju'fì, 83 .

31 The narrative of Ham's curse is directly referenced in another sirrah, that of Sayf b. Dhì Yazan, wherein the white Arabs are pitted against the black Ethiopians and Noah's curse foretells eventual Arab victory (Kruk, 189).

32 Cf. David Goldenberg's description of the "etiology of race" story type, in David M. Goldenberg, The Curse of Ham: Race and Slavery in Early Judaism, Christianity, and Islam (Princeton: Princeton University Press, 2003).
} 
For Tha' labì, the possibility of racial differentiation was latent in Adam, who was made from clay of all colors, pulled from all parts of the earth; racial differentiation merely required a catalyst. ${ }^{33}$ This comes during the flood, when Noah prohibits his family members from sexual intercourse while they are in the ark. Ham defies this ban, and Noah then curses him; thus God alters his nutfah so that he bears black offspring. ${ }^{34}$

Rather than imagining Adam as racially prismatic, Kisā̄ì pictures him as transcending race entirely. His skin is described as almost translucent, with the light of the spirit that God breathed into him shining through it. ${ }^{35}$ Ham's curse in Kisā'î's account more closely mirrors the Biblical narrative, wherein Ham "sees" his father's nakedness and is then censured (Gen. 9:21-27). Ham, according to Kisầì, laughs when Noah's robe slips in his sleep and his genitals are exposed, causing Noah to stir and utter, "What is this laughter? Do you laugh at your father's genitals? May God change your created form [khalqa$k a]$ and blacken your face!" Immediately, Ham's visage turns black. Noah then adds, "may slave women and slaves come from Ham's line, until the Day of Judgment." This command is fulfilled when, while Ham is having intercourse with his wife, God splits open his gall bladder and that of his spouse, such that the black bile produced in the gland mixes with their nutfahs, resulting in a "black slave boy and slave girl [ghulām wa-jāriyyah aswadayn]" being born. ${ }^{36}$

Meanwhile, in al-Jāhiz's creation treatise, al-'Ibar wa-al-itibār, blood has a tincturing effect, albeit temporarily. Unlike in al-Haft al-shariff, blood is rendered here as benign sustenance for the fetus. In a rather bizarre forerunner of the "you are what you eat" adage, al-Jāhiz proposes that different types of nourishment have distinct skin-dyeing effects:

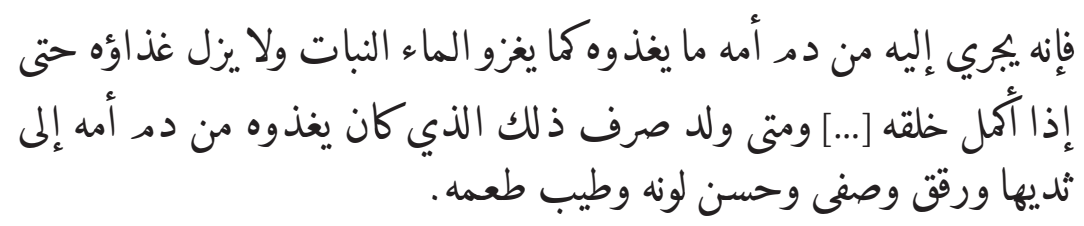

\footnotetext{
33 Aḥmad b. Muḥammad al-Tha'labī and 'Abd Allāh b. As'ad Yāfi'ī, Qișaṣ al-anbiyā’a almusammā bil-arā’is (Cairo: Maktabat al-Jumhūriyyah al-'Arabiyyah, 1900), 22.

34 al-Tha' labī and Ibn As'́ad Yāfíīi, 49.

35 Muhammad b. 'Abd Allāh al-Kisā̄ī, Vita Prophetarum, Auctore Muhammed Ben Abdallah Al-Kisai: Ex Codicibus Qui in Monaco, Bonna, Lugduni-Batavorum, Lipsia et Gothana Asservantur, ed. Isaac Eisenberg (Leiden: Brill, 1922), 26.

36 al-Kisā'ì, 99-10o.
} 
Indeed there runs unto [the fetus] from the blood of his mother that which nourishes him, like water irrigating plants, and his food supply does not abate until once his creation has been completed [...] and when he has been born, that which had nourished him shifts from the blood of his mother to her breasts, and his coloring becomes fair and pure and beautiful when his taste is sweetened. ${ }^{37}$

Implicitly, al-Jāhiz observes that children emerge pink, or "blood-colored," from the womb. Whereas al-Jāhiz attributes the subsequent change in a child's coloration to an improvement in the type of nourishment, hadiths collected by his near-contemporary Ibn Qutaybah instead claim that breast milk creates a conduit between mother and child (or wet-nurse and child) that results in the child's skin tone coming to resemble her own. ${ }^{38}$

The description of 'Abd al-Wahhāb's dark color and features does not conform with these theories. Rather, he emerges from the womb not only with his permanent complexion but also with other mature physiognomic markers. In the passage describing his birth, the child's eyes and brows are described as, respectively, black and beautifully arched; each of these qualities is indicative of quintessentially Arab handsomeness. Indeed, a description exactly identical to that of the newborn 'Abd al-Wahhāb's brows appears in Bayhaqīs (d. 1066) Dalāil al-nubūwah describing the brow line of the Prophet. ${ }^{39}$ This is an initial intimation of what is later confirmed by the first panel of judges to which the child is brought—although his skin is black, 'Abd al-Wahhāb shares his father's physiognomy.

From the outset, 'Abd al-Wahhāb's skin color puts him in harm's way, compelling Fātimah to hide him with one of her servants until, at the age of four, he is brought under her tutelage in Qurān study and martial skills. On the day of his birth, one of the women in Fātimah's retinue notes his complexion and suggests severing his umbilical cord and killing him immediately to "hide the affair, in order that you not remain dishonored until the Day of Reckoning," and advising, lest Fāțimah be accused of adultery, that "the proper thing to

37 Abū 'Uthmān 'Amr ibn Baḥr al-Jāḥiz, al-'Ibar wa-al-'itibār, ed. Șābr Idrīs (Cairo: Al-'Arabī, 1994), 78. (Translations my own.).

38 'Abd Allāh b. Muslim b. Qutaybah, 'Uyūn al-Akhbārr, vol. 2, ed. Abī Muḥammad ibn Qutayh al-Dīnwarī (Cairo: al-Mu’assasah al-Mișriyyah al-Āmmah lil-Ta'līf wa-al-Tarjamah wa-alNashr, 1964), 68.

39 Abū Bakr Aḥmad b. Ḥusayn al-Bayhaqī, Dalā'il al-nubūwah, vol. 1, ed. 'Abd al-Mu'țī Qal'ajī, ed. (Beirut: Dār al-Kutub, 1985), 214-215. 
do is to kill him, and not to perish because of him." The other women agree, and are bemused and aggrieved, having thought Fātimah incapable of such a flagrant transgression. It takes a poetic overture from Fāțimah to convince the women to abandon their murder plot:

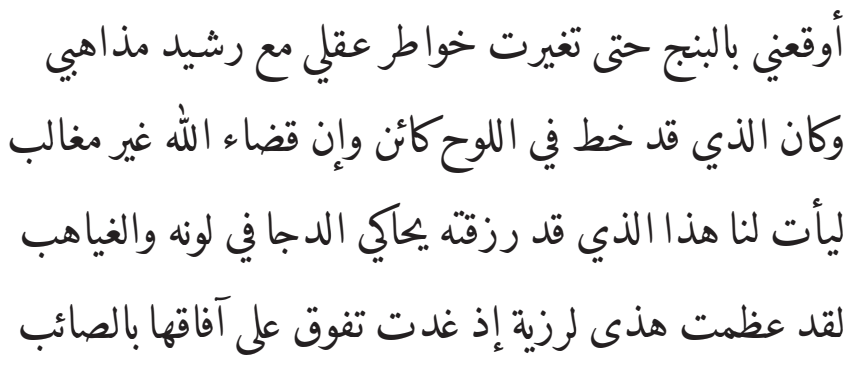

[al-Hārith] dosed me with a drug

Such that my mind's thoughts were altered,

Along with my rightly-guided precepts

And that which was inscribed upon the Tablet shall come into being, Indeed the judgment of God is immutable

For he visited upon us that with which I am endowed

He imitates the starless night in his color, and the jet-black darkness

And indeed my bitterness would only be made greater in this misfortune If I were angry, surpassing the horizons with misery (VII: 12)

Fāțimah emphasizes not only that God has granted her this child according to his will but that she is a woman of superior intellect and morality. She uses three terms to describe her rational faculties—khawațtir, desires or opinions; 'aql, reason or logic; and madhāhib, modes of thought often related to various intellectual pursuits-along with the weighty modifier "rightly-guided" (rashid). When deprived of these faculties, she was placed entirely at the mercy of God and her assailant. Here, though, Fāțimah upholds a narrative of submission to divine will rather than one of victimhood. Moreover, she semiotically repositions her child's blackness using a poetic medium and the elegiac convention of comparing the poem's celebrated subject with natural imagery. Fātimah represents 'Abd al-Wahhāb's blackness as a quality so innate to a constellation of other cosmic phenomena as to be semantically inextricable from their identities. Both the words used for "starless night" and for "jet-black darkness" are derived from roots that signify blackness itself, and that also have more earthly resonances with creatures designated by their dark color through homophony or homography, with the night (duja) calling to mind a dark-feathered thrush 
(dujjā) and the word for a jet-blackness (ghayāhib) a deep black stallion (also ghayāhib). ${ }^{40}$

The double resonance of this line is made all the more distinct through its response to common poetic tropes. Fātimah evokes a thrush over the most common avian analogue for black-skinned people-the crow. The specter of the stallion in the poem draws Fățimah herself into association with the archetypical warrior-poet persona that many heroes in the sirahs channel, as well as offering a premonitory indication of her son's future exploits. Elsewhere, Fāțimah refers to her son's blackness as lustrous (bașșāṣ) and even likens it to the Bayt al-Haram's Black Stone, a trope also found in al-Jāhịiz's epistle in defense of blackness, Fakhr al-sūdān 'alä al-baydānn. Therein, it is noted successively that the Black Stone is from the heavenly garden, and that copper burnished to blackness is the most expensive and prized kind, likewise pairing an image of superficial luster with one of holiness. ${ }^{41}$

It does not take long before, as a youth, 'Abd al-Wahhāb perceives that his color causes his mother social anguish. Tearfully, the boy recites a few lines of poetry, beginning with the declaration "Although I am black, my heart has white upon it, from the shining light of day," and concluding that one's color does not matter, but rather one's deeds (VII: 20). If there were indeed a case to be made for conceptualizing each black hero in the sirrahs as a fresh embodiment of 'Antar, this passage would offer singular support. The racially apologetic content of this line typifies sentiments expressed by a collection of black Arab poets from the Classical period, the "Crows of the Arabs" (aghribat al'arab). More specifically, its wording and meter (wäfir) overtly mimic a brief poem by 'Antarah ibn Shaddād (d. 6o8):

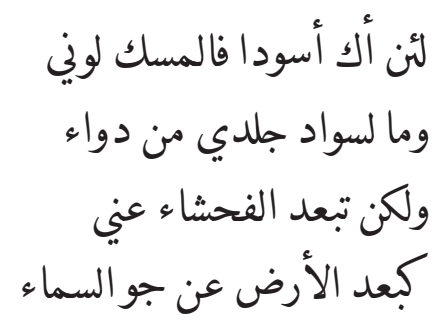

40 Whether the word is dujjā or dujā, given the lack of diacritical marking in the text, cannot be entirely certain. However, if ghayāhib is indeed referring to a horse, then the parallel animal imagery of the thrush becomes the likely choice. As the line is open to either reading, I have incorporated both above.

41 Abū 'Uthmān 'Amr ibn Bakr al-Jāḥiz, Rasā'il al-Jāḥiz, vol. 1, ed. Muḥammad Bāsil 'Uyūn al-Sūd (Beirut: Dār al-Kutub al-'Alamiyyah, 200o), 157. 
Although I am black, my color is that of musk And there is no curative for the blackness of my skin And yet, boorishness distances itself from me, Like the land is distanced from the air of the sky ${ }^{42}$

'Antarah conveys his goodness in a rather different fashion than 'Abd alWahhāb. He likens himself and his black color to musk perfume, the fragrance of which is far more important than its coloration, and which is borne skyward, held aloft from the earthly and profane. 'Abd al-Wahhāb, meanwhile, actively encourages an interpersonal engagement in his poem, seeking to set a performative script that others may imitate by encouraging them to look beyond his surface. Unlike 'Antarah, he does not associate his color with any benign natural image, choosing instead to dismiss it as utterly irrelevant vis-à-vis the valor of his illumined heart, which has the light of day cast upon it, lending it the verisimilitude of whiteness. Whereas it was a common trope among the Crows of the Arabs to claim that although their skin was black, their souls were white, the daylight shining upon 'Abd al-Wahhāb performs a different function. Rather than suggesting that he is intrinsically white in spite of his black skin, the white light of day penetrates through 'Abd al-Wahhāb's exterior and reaches his heart.

By the time his son makes this poetic declamation, al-Ḥārith has been informed about his son and his coloring. He convenes elders from the tribe to wrest a confession of adultery from Fāțimah. In advance of their arrival, alḤārith's first encounter with 'Abd al-Wahhāb is prefigured by a perspectival reorientation. The narrator of the sirah thrusts the reader back into the oral framework of the tale by interrupting with a moralizing aside. In it, he reminds the audience that though 'Abd al-Wahhāb looks like a "Nubian" child, he has a humble heart, and such humility is an adornment that bejewels a "black heart" ("qalb aswad") with redeeming white pearls. ${ }^{43}$ Then, after the repetition of "the narrator said" ("qāla al-rāwa"), doubly jolting the reader back into the role of "listener," the narrator adds, "thus there would be unto this black boy [ghulām] wondrous events and strange affairs, which we shall mention in due time, if God Almighty wills" (VII: 15). 'Abd al-Wahhāb's heroic cycle thereby begins

42 'Antarah b. Shaddād, Dīwān 'Antarah (Beirut: Dār Șādir, 1958), 88.

43 Given 'Abd al-Wahhāb's Arab physiognomy (see below), it is unlikely that analogizing him with Nubians (ka'annahu min awläd al-nübah) is meant to suggest seeming ethnic affinity. Rather, the narrator likely uses "Nubian" as a byword signifying 'Abd al-Wahhāb’s darkness, as opposed to electing a term connoting a connection to Ethiopians or other East African peoples, who were generally thought to have fairer skin. See Lewis, 50-51. 
with a reminder that a hero is presented from birth with challenges that test his innate virtue.

The word ghuläm here is ambivalent, complicating the narrator's statement: it can indicate a slave-boy, as it almost assuredly does in al-Kisāî̀'s description of Ham's progeny, or it may simply mean "boy." Moreover, ghulām is favored over synonyms such as $i b n$ (son) to describe the miraculous children John and Jesus in the Qurān's Sūrat Maryam. ${ }^{44}$ Fāțimah is associated not infrequently with Marian symbolism. Their stories share several features. Both women were impregnated unwittingly by forces beyond their control, and both gave birth to miraculous children who would become defenders of God despite aspersions cast on each woman's chastity and virulent campaigns against their offspring. In light of this relationship and its overall laudatory context in the sirrah, ghuläm could connote positive, scripturally inflected associations as easily as negative, racialized ones.

That this testament to 'Abd al-Wahhāb's future glory is displaced from the characters within the text and voiced instead by the narrator gives it a more generalized, and perhaps apologetic, force in that it interrupts the narrative with the views of a temporally and socially external figure, who speaks up to redeem the black child. 'Abd al-Wahhāb's struggles as a black person are thus framed conspicuously as a retrospective. Though the role of the narrator in textualized sirahs is beyond the scope of this paper, it bears remembering that these texts have experienced centuries of redaction and re-narration. While the narrator's voiceover may be a nod to the sirah's first-hand, recorded quality, its position in the text also renders the figure of the narrator himself as a mediating character who intervenes to instruct the reader in accepting the black hero.

\section{Finding the Father: 'Abd al-Wahhāb's Paternity Trial}

Once al-Hārith and the elders have confirmed 'Abd al-Wahhāb's rumored coloration, legal proceedings ensue. 'Abd al-Wahhāb cycles through several appellate "courts," represented by a provincial judge, a set of Meccan physiognomists ( $q \bar{a} i f$, pl. $q \bar{a} f a h$ ), and finally Ja'far al-Șādiq. The literary function of the physiognomists - the second tier of judges - is essentially to present narratively an otherwise disconnected mélange of haditths, theories, and anecdotes that bear common associations with the adjudication of paternity in an Arabo-Muslim context. 
The primary physiognomist begins by citing the words of the Prophet, stating, "the son is for the [marriage] bed [firäsh]." This may be interpreted as meaning "that any child born to the mother (from any intercourse) should be considered the offspring of her husband or master." 45 The second half of this hadìth, unmentioned in the sìrah, is recorded in Bukhārīs Sahịh as "and for the whore is the stone." ${ }^{46}$ Joseph Schacht has noted that this hadith, were it taken seriously, would have decisively nullified the role of physiognomists in paternity disputes, although this seems not to have been the case in actuality. ${ }^{47}$ Although Bukhārī critiques the use of physiognomists as inciting violence and being useful only in disputes involving harlots and rapists, physiognomists were nonetheless employed in prominent positions well into the Ottoman period, occupying varying roles over time as legal and political advisors. The content of this particular hadith developed into an actionable legal citation; according to Uri Rubin, claims of firäsh were indeed believed by some jurists to abrogate the role of physiognomists when used to formally contest a di'wah, or extra-marital paternity claim. ${ }^{48}$

As such, in opening with this hadith, the physiognomists acknowledge an apposite legal method. A final possibility is that this hadith recitation evokes a theme that recurs throughout the sirah: the text acknowledges that the sciences are superficially useful tools, yet maintains that they cannot ultimately contravene what was believed to be the word of God or his messenger.

The head physiognomist proceeds with his work after this ambivalent introduction, saying,

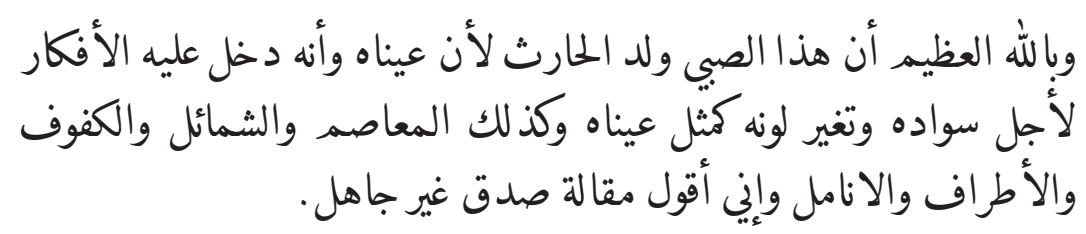

By God the Great, indeed this youth is the son of al-Hārith, for his eyesalthough he allowed thoughts to impinge upon him, causing his son's

Uri Rubin, “'Al-Walad li-l-Firāsh' on the Islamic Campaign against 'Zinā,'” Studia Islamica 78 (1993), 5 .

46 Aḥmad b. 'Alī b. Hujr al-'Asqalānī, "Bāb al-walad lil-firāsh ḥurrah kānat āw amah," in Fatḥ al-barī: sharḥ șaḥ̄h al-Bukhārī (al-Maktabah al-Islāmiyyah, 1996), http://library.islamweb .net/newlibrary/display_book.php?idfrom $=12367 \&$ \&idto $=12370 \& b k \_n o=52 \& I D=3723$. Joseph Schacht, "Foreign Elements in Ancient Islamic Law," Journal of Comparative Legislation and International Law 32 (1950), 5 .

48 Rubin, 11-12. 
blackness and the change in his color-are like unto his eyes, and likewise with the bone structure and the [other] traits, and the palms of the hands, and the extremities, and the fingertips, and indeed I deliver a truthful report, not an ignorant one [...] (VII: 34)

In alluding to the offending thoughts (afkār) that al-Hâarith failed to keep at bay during intercourse, the physiognomist asserts that al-Hārith is not only the father of the child, but moreover that he is responsible for the alteration to his son's color due to some kind of conscious or unconscious ideation. Al-Hārith roundly refutes having had fantasies that "imprinted" his son during intercourse, though in so doing he and the physiognomist touch upon a pseudo-scientific discourse found in several sources, both Classical and medieval. Cases of "image-imprinting," or impressing a birthmark or defect on a child through acts of sexual fantasy or psycho-emotional fixation, are attested in many cultures ${ }^{49}$ One prominent instance in adab sources is found in Ibn Ḥazm's Ṭawq al-hamāmah (The Dove's Neck-Ring). Ibn Ḥazm relates the Biblical account of Jacob's stripping poplar branches and setting the wood before his flock's trough (Gen. 30:37-39). After seeing the mottled bark whenever they feed, the sheep mimetically calve spotted offspring. To this, Ibn Hazm adds, "also, one physiognomist gives an account of a black child brought forth from white parents." Then he recalls the tale of a white man and woman who give birth to a black child because of a portrait of a black man hung on the wall, upon which the woman fixed her eyes during sex. ${ }^{50}$ This story, for Ibn Hazm, constitutes an example of how images stimulate lust, the cautionary aspect of which is evident. Implicitly, curating a woman's environment and limiting objects for her potential stimulation also limits reproductive risk, represented by the black child, who is a physically hyper-marked proxy for a bastard. The sirah, in grappling with a similar set of concerns over 'Abd al-Wahhāb's

What is referred to here as "image-imprinting" is often designated "maternal impression," attesting to the oddity of this outcome being the responsibility of the male partner, as with al-Hārith. Several literary works in the European tradition take maternal impression as a central element, and it features in Galenic medicine as well, though again with the mother empowered as the sole "impresser." See Graham Anderson, "Two Notes on Heliodorus," The Journal of Hellenic Studies 99 (1979), 149; Cristina Mazzoni, Maternal Impressions: Pregnancy and Childbirth in Literature and Theory (Ithaca: Cornell University Press, 2002), 16-17. On Middle Eastern folk beliefs about maternal impression during pregnancy, see Remke Kruk, "Pregnancy and Its Social Consequences in Mediaeval and Traditional Arab Society," Quaderni Di Studi Arabi 5/6 (1987-1988), 426-428. 
legitimate paternity, raises a similar theory, which shifts the blame for the child's condition from a question of physical infidelity to a question of emotional infidelity. In this fashion, blackness is represented as the physical symptom (albeit displaced onto one's offspring) of an ailment of the mind, whereas the majority of the theories raised throughout the sirah and its companion sources meditate mostly on bodily defects.

After pronouncing on al-Hārith's thoughts during coitus, the physiognomists invite all of the men in the room to walk alongside 'Abd al-Wahhāb across sand strewn on the floor. They then judge from the similarity between his footprints and those of al-Hārith, in conjunction with their other common physical features, that al-Hārith is indeed the father. Unsatisfied, alHārith mocks the physiognomists' approach and threatens to kill his wife and son. Al-Hārith's father recites some palliative verses assuring him that 'Abd al-Wahhāb is a bastard, likening his origins to those of dogs - an insinuation of Fātimah's promiscuity - and his appearance to a crow. These verses are reminiscent of a poem recited earlier by al-Ḥārith when he accused Fāțimah of adultery:

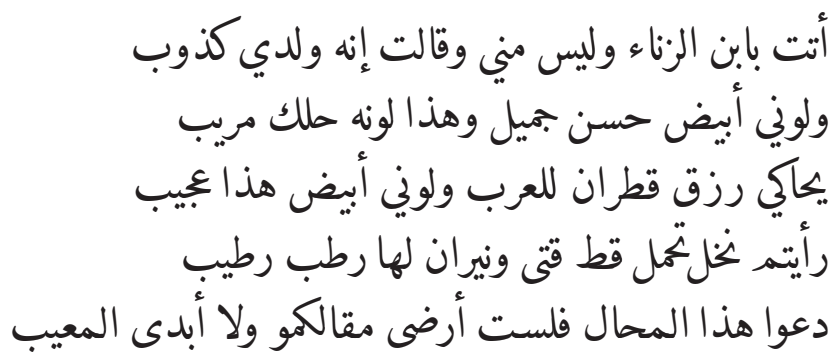

She bore a bastard son, and he is not from me

Though she said that he is my son-liar!

For my color is white, beautiful, and good

And this color of his is suspiciously dark

The "boon" [of a child] strikes a semblance with tar for the Arabs

And my color is white-this is strange

Have you ever before seen date-palms bearing cucumbers?

Or flames with moist, fresh dates?

Leave off with this absurdity, I do not accept your words

And I won't countenance [such] disgrace (VII: 16)

The deep brown dates simmering in flame evoke not only the paradoxical marriage of water and fire, but perhaps also Fāțimah's non-normative passions for the imagined brown-skinned man that al-Hārith interpolates as his 
adulterous wife's lover. The bizarre and priapic image of the cucumbers hung from date palms further accentuates this theme of sexual deviance. Insulting 'Abd al-Wahhāb's complexion as resembling "tar" draws on a common racial cliché. And yet, the word for young dates (ruțab) recalls the Qur'ānic image of when Mary, while in labor, is given a date palm by God and instructed to sustain herself with its fruits (Q 19:25). These fruits and the desert palms that bear them echo Fāțimah's remarkable fecundity, posed against the adverse environment of flame. Similarly, in Sürat Maryam, the miraculous appearance of a palm in full fruit reflects Mary's own miraculous pregnancy, and moreover is sent to shade and comfort her as she gives birth in isolation. Fittingly, the "palms" (nakhïl) are the subject of the verb tahmal, "to bear," conjugated in the feminine. This links the fructification of the palms even more explicitly to childbearing. Even when impugning her, al-Ḥārith selects images that ironically reinforce Fāțimah's chastity and forbearance.

Not all agree with al-Hārith's view of his own white complexion. In the midst of the argument, one of Fātimah's defenders says, "do you not see regarding the child that his mother is radiantly white, and his father though fair is speckled, bringing about his color-a leathery black?" In using causal language to adduce al-Hārith's complexional defect as that which "brings about" the black skin of 'Abd al-Wahhāb, the anonymous commenter implies that Al-Ḥārith's allegedly "speckled" skin carries with it a hereditary potential that is expressed in exaggerated fashion in his child's complexion. Though al-Hārith's ancestors are not likewise described, the implication may even be that 'Abd al-Wahhāb presents in full force the trait of blackness that al-Hārith carried forward, and even presented, albeit in an atrophied way. This passage seems to subtly reference the theory of atavism, an Aristotelian view in which individuals may present reversionary characteristics that have not manifested for generations. ${ }^{51}$ This rationalization does not resurface elsewhere, but its use indicates at least tangential familiarity with a principal Classical theory explaining how blackness can derive from whiteness.

At the suggestion of the physiognomists, Jaffar al-Ṣadiq is sought to offer the final word. From the outset, the imam is described in a manner indicating that his judgment will be incontrovertible. First, his kinship with the Prophet is referenced. He is then described as a "trove of virtue [futuwwah]," who dispels anxieties and showers generosity upon the downtrodden. When the assembled crowd sees him, they remark on his "Alid aspect and patent Hashemite roots," further underscoring the significance of physiognomy within the text.

During his judgment, Ja'far al-Ṣādiq compels al-Ḥārith to confess that he copulated with Fātimah while she was menstruating. In light of this, Jafar 
blames the coloration of the fetus on the mixing of menstrual blood with the embryogenic nutfah. In so doing, though, he must explain how it is that such a mixture would tint the fetus black and not red. Ja'far al-Ṣādiq's character finds recourse in a distinction that is highly debated in early exegesis and jurisprudence, namely, the difference between a woman who is a $h \bar{a}{ }^{\prime} i d$ (menstruant) and one who is a mustahâa

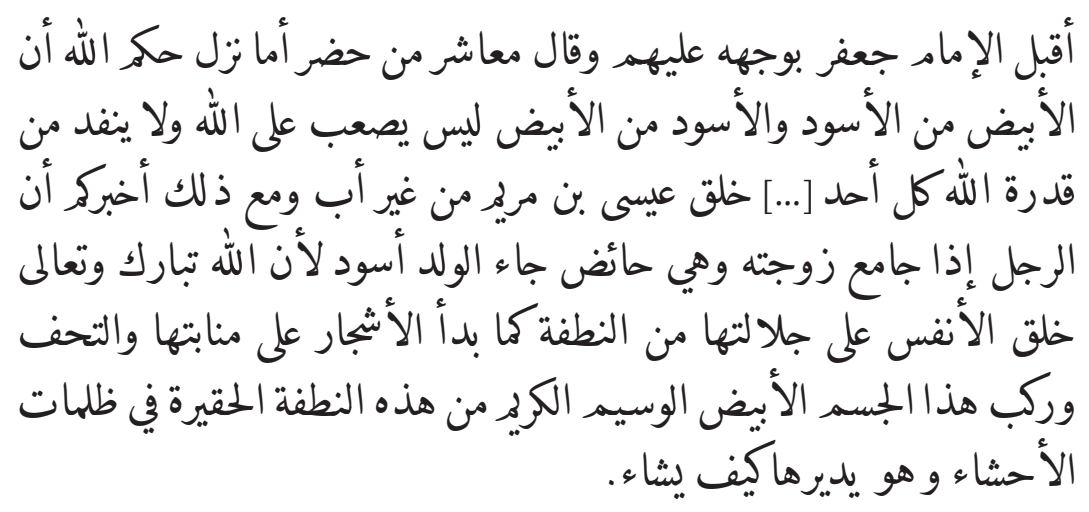

[T] he imam Jacfar turned his face to them and said, "People who are in attendance, has not the judgment of God been revealed, that white may come from black and black from white? This poses no difficulty for God, nor does anything exhaust the power of God-not one thing! [...] He created Jesus son of Mary without a father, and moreover I inform you that if a man copulates with his wife and she is menstruating, the child will emerge black because God, blessed and glorious, created the souls, in their sublimity, from a sperm-droplet just as he initiated the trees upon [the process of] their germinating. And he enwrapped and assembled this white, handsome, noble body from this vulgar droplet in the darkness of the womb and he conducts it however he wills." (VII: 39)

Jacfar then questions al-Ḥārith, who admits that Fāțimah was menstruating at the time of their sexual encounter. To this, Ja'far responds using an analogous case that was brought before his forefather, the Prophet Muhammad:

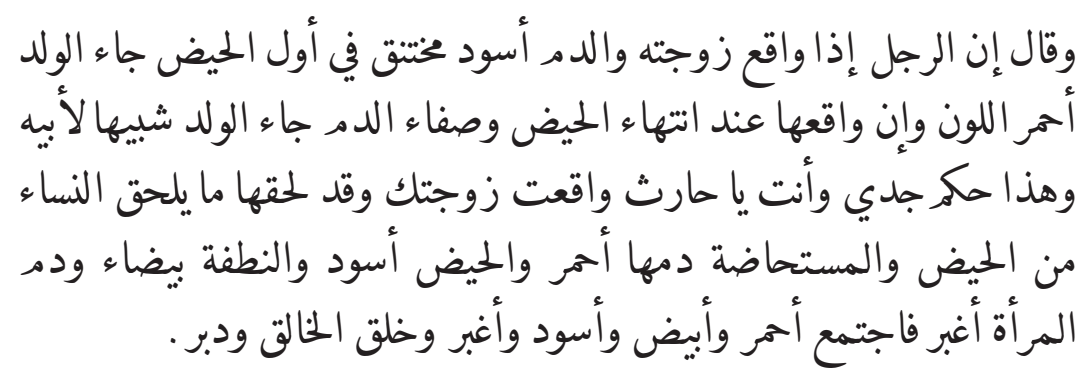


And [Muhammad] said that the man, should he copulate with his wife while the blood is black and stopped-up at the beginning portion of the menses, the boy will become red in color, and if he has intercourse with her at the end of the menses, when the blood is pure, the child comes to resemble his father, and this is my ancestor's judgment. And you, oh Ḥārith, had sex with your wife while there clung to her whatever adheres to women of the menses - and [as for] the metrorrhagic woman, her blood is red, and the menses is black and the sperm droplet is white and the blood of woman is dust-colored, so the red and white and black and dust-color melded and the Creator created and arranged [him]. (VII: 39)

Several early comprehensive tafsir works grapple with this distinction between $h \bar{a} i$ i and mustahạdah in exegeses of a verse of Sürat al-baqarah that states, "And should they ask you about menstruation, say, 'it is harm [adhā], so withdraw from women during menstruation'” ( $Q$ 2:222). Many of these debates are preoccupied mainly with the question of timing. Some attest that istihadah represents spotting, while others define it as the condition when menstruation extends beyond a certain point, often ten or fifteen days. ${ }^{52}$ Qurțubī (d. 1273), writing later, adds a distinction with respect to the type of blood, claiming that dam al-hayd is initially black and thick, but is later overwhelmed by red blood.53 That is, Qurțubī, like the fictional Ja'far al-Ṣādiq, offers a color- and consistency-based timetable of menstrual blood types.

Fāṭimah is not asked to confirm whether she was menstruating or which stage of menstruation she was in; rather, the evidence is clearly inscribed on her son's flesh. Nor does Fātimah's rape become a feature of legal consideration; she does not disclose it, and who else would on her behalf? Instead, the seeming violence of her assault is diminished by Jafar's judgment: Fāțimah having been left bleeding by her husband no longer connotes possible battery or her hymen tearing open, but simply an instance of lust prevailing over perspicuity. Al-Ḥārith must not have noticed her bleeding prior to his attack.

Though his tafsīr postdates most of this article's primary sources, al-Qurțubī cites the views of earlier jurists on this debate, with al-Shāf'i 1 (d. 820), for example, asserting that a woman is metrorrhagic if she bleeds for less than one full day or exceeding fifteen days; Abī 'Abd Allāh Muḥammad b. Aḥmad al-Anșārī al-Qurțubī, al-Jām‘i li-ị̣kām al-Qur'ān, vol. 3 (Cairo: Dār al-Kutub, 1967), 83; Marion Katz, "Scholarly versus Women's Authority in the Islamic Law of Menstrual Purity," in Gender in Judaism and Islam: Common Lives, Uncommon Heritage, ed. Firoozeh Kashani-Sabet and Beth S. Wenger (New York: New York University Press, 2015), 73-105. al-Qurțubī, 82. 
There is a critical disconnect, however, between the emission of this black blood from the feminine subject and the resemblance that it forges between the child and the masculine agent. Ja'far al-Ṣādiq enigmatically mentions that the "purity" of the blood causes the child to "resemble his father." The notion of purity here may refer to the chromatic saturation of the substance, meaning that it is a very pure, consistent black. Nonetheless, the blood's causal link to paternal resemblance is not immediately intelligible. It is for this reason that the double entendre through which the word for "purity" (safä) may alternatively mean "pleasure" or "contentment" is suggestive. As expressed in a hadith recorded by the "real" Ja'far al-Ṣādiq about the color, viscosity, and potency of male and female nutfah, the first individual to ejaculate during copulation was thought to bear primary responsibility for the child's appearance: if "the water of the man precedes the water of the woman," then the child will resemble the paternal line, and vice versa. ${ }^{54}$

By extension, if menstruation is a harm or pain for a woman, and her blood meanwhile offers enjoyment to her male partner, he necessarily will be the first to orgasm. As such, the mother's black blood counterintuitively leads the child to resemble his father, and therefore maintains a mutual culpability for the child's coloring: his father contributes the initial "motive force" (his ejaculate) and his mother, unwittingly and unwillingly, provides the impetus to that motive force as well as the material upon which it acts (her blood).

In light of the speculative association between menstrual blood and moral depravity in al-Haft al-sharîf, allegedly compiled from Jaffar al-Ṣādiq's sayings, we may moreover read the process by which a man is enticed to copulate with a menstruant and the ensuing effect of his child bearing an uncanny resemblance to him as a mechanism for moral refraction. The father who sired a child while his partner was menstruating, upon meeting that child, is met with a tainted image of himself. In rejecting this image by claiming that it is a product of sin - in this case, of adultery - the father ironically repudiates his own behavior. This is not to say that the composers of Sirat dhät al-himmah were necessarily acquainted with Jafar al-Ṣādiq's views on menstrual blood and ensoulment, but rather that they may be cuing into the more basic trope of inventive and often ironic reprisals for sin, as with Ibn Hazm's woman with the wayward fantasies, who gazed desiringly on a black man's portrait during intercourse, resulting in a black child.

Added to the malefaction of menstrual sex is al-Ḥārith's unwillingness to claim his resultant child. His act of paternal rejection is not a unique one; a

54 Jađar al-Ṣadiq and Muhsin 'Aqīl, Ṭibb al-imām al-Ṣādiq (Beirut: Mu’assasat al-I'lāmī, 1998), 520. 
similar event precipitated Fāțimah's own heroic ascent. Mortified at having had a daughter instead of a son, Fāțimah's father nearly committed infanticide. He was narrowly coaxed out of doing so by a slave woman, who then took Fāțimah into her care, only to be captured by a rival tribe. ${ }^{55}$ It was in this environment of estrangement, fatherlessness, and male duress that Fāțimah began to show her martial prowess. Both instances of rejection buttress the sirah's refrain that one's actions can eclipse deficiencies of pedigree or social esteem.

The formative challenges faced by both mother and son stem from their naturally (or unnaturally) constituted marginality, that is, their gender and race. This is thrown into sharp relief by the results of the trial. Fātimah's exoneration comes at the price of having aspects of her bodily functions put on public display, after having already had her body violated and impregnated against her will. 'Abd al-Wahhāb's blackness is rendered not only as socially downgrading, but also chemically grotesque through its association with the denaturalizing taboo of menstrual sex. This grotesqueness directly undermines attempts, such as Fātimah's praise-poem for her child, to naturalize blackness through its association with benign images. Although the alternative taboo of 'Abd al-Wahhāb's potential black father is disproven, this is only achieved through the exposure of a mystifying, contemptible act that thwarts conventional biological formulae.

Even so, Ja'far al-Ṣādiq interprets Fāṭimah's case through analogy with biologically non-normative acts of divine providence, rather than those of earthly accident. Again, the image of Mary is cited, associating Fātimah with the divine providence by which maternity is administered. Nevertheless, Mary's narrative holds only a tentative analogy with Fātimah's case, for unlike Jesus - the only human after Adam and Eve created without the nutfah's "disdained water" ( $\left.m \bar{a}^{\prime} m a h \bar{i} n\right)$ - it is the vulnerability of the nutfah itself that enables the alteration of 'Abd al-Wahhāb's form. ${ }^{56}$

\section{Conclusion}

Despite Fāțimah's chastity, 'Abd al-Wahhāb’s virtue, and their mutual attempts to affirm their humanity, ultimately Ja far, the story's final and most authoritative judge, concludes that 'Abd al-Wahhāb diverges etiologically from virtually every other being. The fault for this lies with his mother's menstrual emission. The medical oddity of 'Abd al-Wahhāb's birth at once engenders his identity as a black male and precludes the full realization of his membership within

55 Lyons, Arabian Epic, 319.

56 Cf. Q 32:8, Q 77:20. 
a broader community or group of black people. Although his blackness is not ancestral, his experiences are inevitably premised upon a historical narrative out of which black identity is hewn. That is, throughout his adventures, 'Abd al-Wahhāb's compatriots and critics alike assume that he is of sub-Saharan African heritage, and therefore that he is a slave or slave-born. This ostensibly reasonable assumption re-poses, with each new encounter, the question of legitimacy that is originally foisted upon 'Abd al-Wahhāb's character. To this issue of 'Abd al-Wahhāb's legitimacy, several heuristic tools are applied, each of which expresses a different theory of how racial differentiation can occur seemingly ex nihilo: image-imprinting, contamination of the nutfah, and sheer divine providence. As distinct from late Antique racialist ideas of climatology and atavism and Abrahamic notions of Hamitic genealogy, none of these theories adduces even the most distant African heritage as a contributing factor in 'Abd al-Wahhāb's appearance.

This article has argued that all of these racialist heuristics share an overarching theme of anxiety over the female body's sexual and biological vulnerability, which is cautionarily represented through the construction of a black body. This black (male) body becomes the instrument through which the instabilities of the female body are scientifically reified again and again throughout the text. Such a thesis contains a certain risk, in that in focusing on a particularly passive moment for 'Abd al-Wahhāb in the text—a moment in which his black body is literally being produced - it is complicit in the erasure of a black character's agency, rendering him as ontologically contingent on a white woman. The problem of such erasures is an enduring one, and this article aims to add to it the question of how scholars of Arabic literature might engage such erasures. In a similar fashion, historian Chouki El Hamel has recently sought to account for the social expurgation of "Africanicity" - which he defines as "black consciousness" - in the Maghreb, which effectively results in the rhetorical disempowerment of collective memories of black slavery in the region. To this point, he quotes a Mauritanian scholar as saying, "the culture of the Haratin [former black slaves] has been erased." ${ }^{57}$ The dislocation of 'Abd al-Wahhāb's blackness from any kind of African heritage in Sirat dhät al-himmah may indicate that such erasures have been occurring for far longer than supposed. Indeed, in reading 'Abd al-Wahhāb's unique plight against Boulou Ebanda de B'Béri's definition of Africanicity as, in part, "an articulation of re-enactment, which uses affective cords of racial belonging to create a sense of communality, or the commentary of recognition," we find that the "affective cords" entwining

57 Chouki El Hamel, Black Morocco: A History of Slavery, Race, and Islam (New York: Cambridge University Press, 2014), 2. 
'Abd al-Wahhāb weave him not into a common set of experiences, but rather dangle him as a stray thread disowned from a greater cultural fabric-be it African or Arab. 58

In many ways, 'Abd al-Wahhāb's blackness is complicated for the very reason that it does not have the weight of history behind it. Instead, it situates itself within a network of scientific and speculative discourses such as those in the companion texts introduced in this article. Through these discourses, 'Abd al-Wahhāb becomes radically isolated as a character type; the effect of applying these putatively naturalist theories to explain his blackness is, in fact, to render him as the product of deviant intercourse and aberrant biology. 'Abd al-Wahhāb and his other non-hereditarily black peers in the sirrahs share not only in their defining supernatural heroism, but also in this more esoteric form of difference.

$5^{8}$ Boulou Ebanda de B’Béri, "Africanicity in Black Cinema: A conjunctural ground for new expressions of identity," in Africa: Cultural Studies and Difference, ed. Keyan G. Tomaselli and Handel Kashope Wright (New York: Routledge, 2011), 25. 